\title{
Pattern of Genetic Divergence of Mitochondrial DNA Sequences in Biomphalaria tenagophila Complex Species Based on Barcode and Morphological Analysis
}

\author{
Roseli Tuan, Fernanda Pires Ohlweiler, Raquel Gardini Sanches Palasio, \\ Ricardo Dalla Zanna and Marisa Cristina De Almeida Guimarães \\ Superintendência de Controle de Endemias, São Paulo \\ Brazil
}

\section{Introduction}

Neotropical region has a high diversity of Biomphalaria (Pulmonata: Basommatophora: Planorbidae) fauna with at least twenty-six of the world's estimated thirty- seven species recorded (Carvalho,2008). Nearly one -third of these species occur in freshwater ecosystems related to the main drainage river basins in Brazil (Estrada et al.,2006; Teodoro,2010), where Biomphalaria glabrata (Say,1818),Biomphalaria tenagophila (Orbigny,1835) and Biomphalaria straminea (Dunker,1848) have serious impact on human health for these species host Schistosoma mansoni Sambon 1907 (Figure 1).

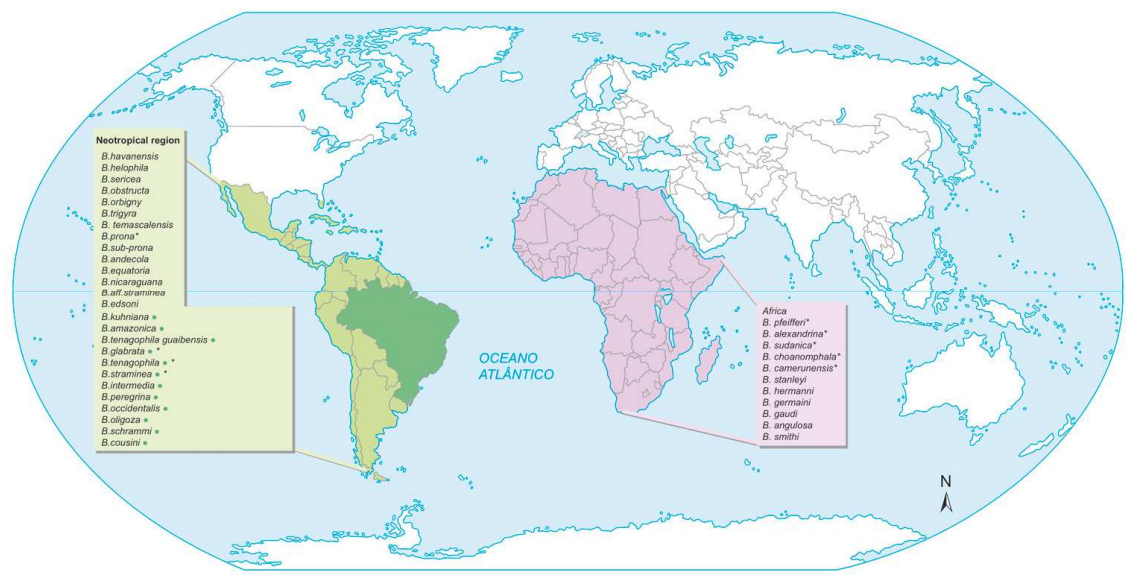

Fig. 1. Map (according Palasio, R.G.S., 2011) showing the worldwide distribution of the 37 Biomphalaria species, the 26 neotropical Biomphalaria species and the 11 species and 1 subspecies naturally described in Brazil (•) (Brasil,Ministério da Saúde 2007; Carvalho et al., 2008; Teodoro et al.,2010). An asterisk indicates Schistosoma mansoni host species (Palasio, RGS, 2011). 
B. tenagophila is the nominal member of a species complex of freshwater snails distributed widespread in the neotropical region (Figure 2). B. tenagophila is the main host of S. mansoni in the southeastern Brazil. (Paraense \& Corrêa,1978).As currently defined, the B. tenagophila complex includes a sub-species B. tenagophila guaibensis (Paraense,1984) and a species B. occidentalis (Paraense,1981).

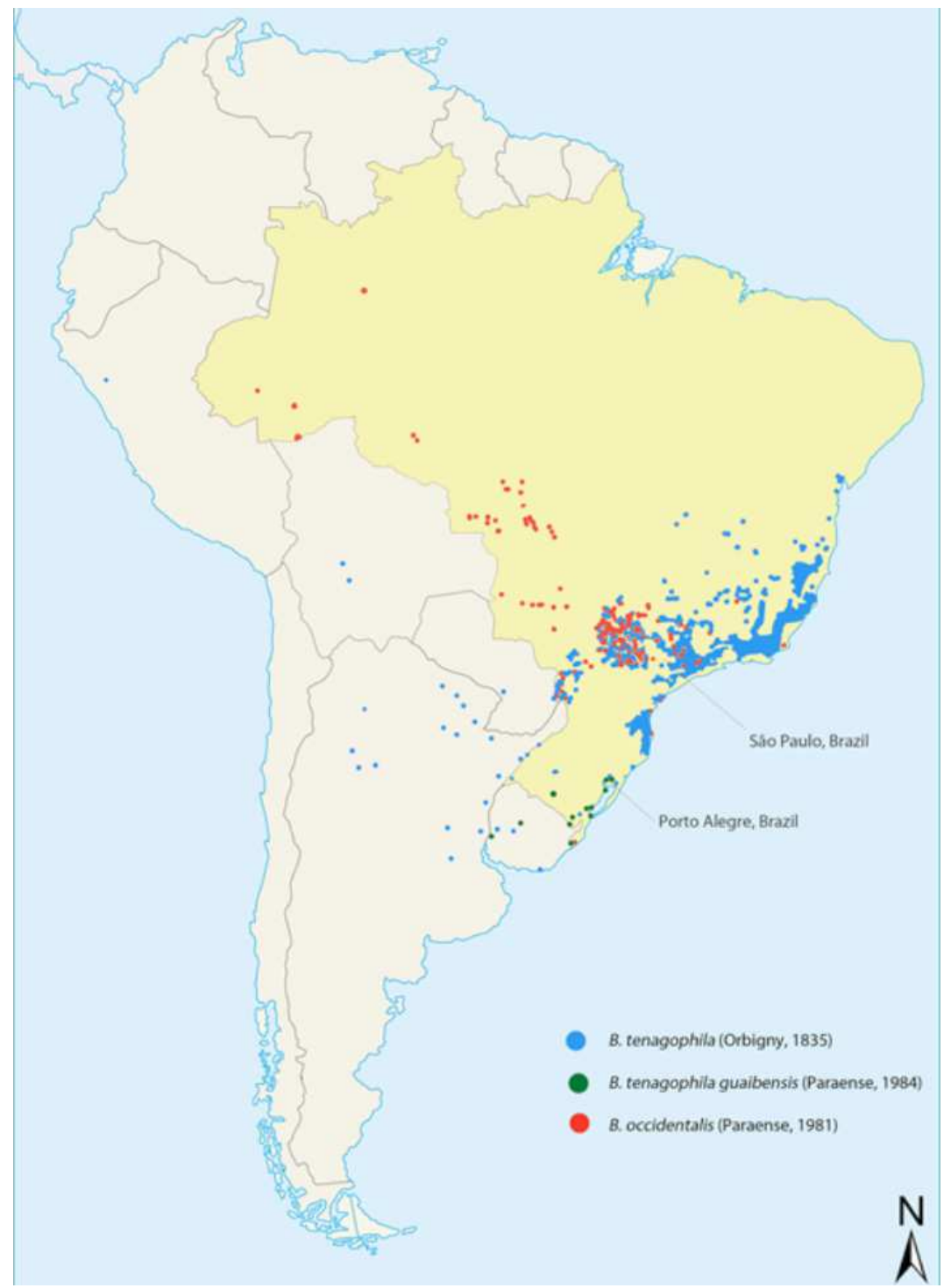

Fig. 2. Geographic distribution of Biomphalaria tenagophila complex in the southeastern Brazil. (R.G.S. Palasio \& R. Tuan based on illustrations in Lima et al.,1993; Paraense 1984, 2001; Carvalho \& Caldeira,2004). 
The morphological characters of the genital organs employed by the malacologist WL Paraense permits all of us to correctly identify the taxonomic units of the tenagophila complex. But,in fact,identifying Biomphalaria species solely on morphological characters leads to a less precise identification of these taxonomical groups, which are found to be difficult to diagnose in a malacological work routine.

The following examples may illustrate how morphological or technical variations can lead to erroneous species identification with serious epidemiological consequences.

Example 1: Within the species of planorbid described in Brazil,a B. glabrata is the only species to feature pigmented renal ridge (Paraense and Deslandes 1959). This character is known to be the only to set the difference between $B$. glabrata (the most important host species of $S$. mansoni in the Americas) and $B$. tenagophila,responsible for the transmission of schistosomiasis in the southeastern region of Brazil. Pepe et al. (2009) reports that a pigmentation-like may appear associated to the renal ridge in $B$. $t$. guaibensis, as a result from an intraspecies variation. Such diagnosis would trigger an unnecessary alert once B.t.guaibensis is not an intermediary host of S. mansoni.

Variation in the pattern of the pigmentation of the renal ridge may also reflect the influences of the freshwater substrate types leading us to an erroneous identification of all Biomphalaria species.

Here we exemplified the two major aggravating factors in a morphological identification system: morph variation within the species and variation caused by interaction of the organism with the environment.

Example 2: According to Paraense (1984) an essential condition for a clear distinction of B.tenagophila from the subspecies B. t. guaibensis "is that the animal body is preserved for dissection in a well relaxed condition", that is,for the identification of the subspecies,more rigorous laboratorial methods of looseness need to be used instead of the methods utilized in the current identification of mollusks. If the B.t. guaibensis subspecies were dispersed,it would be difficult to have a morphological differential diagnosis of these subspecies.

The intrinsic difficulties to the system of morphological identification of organisms limit the description of taxonomic discreet units,although they lead to the development of auxiliary molecular techniques to overcome these difficulties (Estrada et al.,2006; Carvalho,2008).

Species of planorbid snails belonging to the genus Biomphalaria have received increasing attention in molecular systematic and phylogeographic studies in recent years (Vidigal et al. 2000,2004; Carvalho et al. 2001; DeJong et al. 2001,2003; Mavárez et al. 2002a,b; Morgan et al. 2002; Pointier et al. 2005; Tuan and Santos,2007). The development of genetic markers and the databases generated in such studies can be further used for multiple purposes,of both theoretical and applied interest: species identification,analysis of population genetic structure and speciation patterns,inference of common/independent origins of susceptibility to Schistosoma,detection of natural hybridization,tracking of geographical expansions and biological invasions,evaluation of genetic differentiation between phenotypic variants and/or geographic isolates,amongst others. Genetic markers used in Biomphalaria studies include mitochondrial DNA (Spatz et al. 1999; DeJong et al. 2001,2003; Mavárez et al. 2002b; Pointier et al. 2005). The latter is especially useful for species identification.

The dispersal and colonizing ability of $B$. tenagophila highlights the need to monitor the spread of this species within and outside the neotropical region. The identification of $B$. tenagophila in Kinshasa,Africa (Pointier,2005) and Romania (Majoros et al. 2008) certainly caused great concern to public health authorities. 
For Biomphlalaria species two important characteristics play an important role to successfully establish snail populations in a environment outside the native range of the species: self-fertilization and desiccation. B.tenagophila species are simultaneous hermaphrodites snails with the possibility of both self and cross-fertilization (Paraense,1955; Tuan \& Simões,1989; Guimarães,2003). Such a complex mode of reproduction might probably increase colonization since new populations can arise from just one snail by self-fertilization.

On the other hand reproduction alone is not enough to establish a species because snails still must be able to survive conditions outside their native range. One important aspect to $B$. tenagophila survival it is the ability to withstand desiccation in response to water shortage (Tuan \& Simões,1989; Ohlweiler \& Kawano,2002) that greatly increases the possibility of recolonization after a population crash or colonization of new environments. These must be a major source of genetic diversity amongst the same species creating patchily distributed populations that can be easily distinguished by molecular markers.

In this study,we obtained mitochondrial COI and 16SrRNA sequences from $B$. tenagophila, $B$. t. guaibensis, and B. occidentalis specimens collected in the São Paulo state, and Rio Grande do Sul state,Brazil to estimate the divergence of each species amongst the three members of the tenagophila complex and evaluate the potential of COI and 16S rRNA mitochondrial genes for identification of closely related species.

\section{Materials and methods}

\subsection{Molecular analysis}

B. tenagophila and B. occidentallis snails were collected along the banks of different streams of Paranapanema,Ribeira do Iguape,Paraíba do Sul,Tietê,and Litoral Basins at São Paulo,Brazil. B.t. guaibensis specimens were collected at Rio Grande do Sul,Brazil (Table 1). Two samples from Argentina were also analyzed. A total of 66 specimens were used in this study. Prior to molecular analysis snails were identified through morphological analysis,according to Deslandes (1959) and Paraense (1975,1981, and 1984).

Total genomic DNA was extracted from foot tissue of individual snails using DNeasy Tissue Kits (Qiagen ${ }^{\circledR}$ ) and was preserved as DNA vouchers specimens in the DNA voucher collection of the Laboratory of Molecular Biology and Biochemical at SUCEN. Amplification of COI gene was attempted using LCO-1490 and HCO-2198 (Folmer et al.,1994). Amplifications (in 50 $\mu$ l of total volume) consisted of 10-100 ng of DNA,0.2 mM of each dNTP, $0.10 \mu \mathrm{M}$ of each primer and $1 \mathrm{U}$ of Taq DNA polymerase (BioLabs) with the supplied buffer. The following PCR temperature profile was used: a initial 3 min step at $95^{\circ} \mathrm{C}$ for denaturation, 25 iterations of $1 \mathrm{~min}$ at $95^{\circ} \mathrm{C}, 1 \mathrm{~min}$ at $47^{\circ} \mathrm{C}$ and $1 \mathrm{~min} 30 \mathrm{sec}$ at $72^{\circ} \mathrm{C}$, and a final extension step for $7 \mathrm{~min}$ at $72^{\circ} \mathrm{C}$. The amplification profile of 16SrRNA fragment included an initial denaturation step at $94^{\circ} \mathrm{C}$ for $2 \mathrm{~min}$. and 35 cycles of $30 \mathrm{sec}$ at $94^{\circ} \mathrm{C}, 30 \mathrm{sec}$ at $54^{\circ} \mathrm{C}$ and 1 minute at $72^{\circ} \mathrm{C}$, and a final step at $72^{\circ} \mathrm{C}$ for 5 minutes. Amplification of 165 gene was attempted using a Palumbi forward and reverse primer (Palumbi, 1996).

PCR products were checked by agarose gel electrophoresis,cleaned using QIAquick PCR Purification Kits (Qiagen $\left.{ }^{\circledR}\right)$. Cycle-sequencing of PCR products were carried out using terminal primers given above and the BigDye Terminator v3.1 kit of Applied Biosystems (ABI),purified using DyeEx-Kit (Qiagen $\AA$ ) according to the modified protocol and sequenced on an ABI 310 automated sequencer. 


\begin{tabular}{|c|c|c|}
\hline Species/Locality & Code & Geographical coordinates \\
\hline \multicolumn{3}{|l|}{ B. tenagophila } \\
\hline Ourinhos (SP),Brazil & Btt_Our1 -6 & $22^{\circ} 58^{\prime} 02^{\prime \prime S} 49^{\circ} 52^{\prime \prime} 25^{\prime \prime} \mathrm{W}$ \\
\hline Ipauçu (SP),Brazil & Btt_Juq1-8 & $23^{\circ} 02^{\prime} 54^{\prime \prime} \mathrm{S} 49^{\circ} 34^{\prime} 41^{\prime \prime} \mathrm{W}$ \\
\hline Taubaté (SP),Brazil & Btt_Tau1-3 & 2301'35"S $45^{\circ} 33^{\prime} 21^{\prime \prime} \mathrm{W}$ \\
\hline Pindamonhangaba (SP),Brazil & Btt_Pin1-2 & $22^{\circ} 53^{\prime} 30^{\prime \prime} \mathrm{S} 45^{\circ} 28^{\prime} 09^{\prime \prime} \mathrm{W}$ \\
\hline Caraguatatuba (SP),Brazil & Btt_Car1-7 & 233'ㄱ' $31^{\prime \prime S} 45^{\circ} 24^{\prime} 44^{\prime \prime} \mathrm{W}$ \\
\hline São Sebastião (SP),Brazil & Btt_SSe1 & $23^{\circ} 47^{\prime} 08^{\prime \prime} \mathrm{S} 45^{\circ} 33^{\prime} 22^{\prime \prime} \mathrm{W}$ \\
\hline Campinas (SP),Brazil & Btt_Cam1-4 & $23^{\circ} 02^{\prime} 13^{\prime \prime} \mathrm{S} 47^{\circ} 06^{\prime} 21^{\prime \prime} \mathrm{W}$ \\
\hline Sorocaba (SP),Brazil & Btt_Sor1-5 & $23^{\circ} 29^{\prime} 56^{\prime \prime S} 47^{\circ} 27^{\prime} 30^{\prime \prime} \mathrm{W}$ \\
\hline Registro (SP),Brazil & Btt_Reg1-3 & $24^{\circ} 29^{\prime} 20^{\prime \prime} \mathrm{S} 47^{\circ} 51^{\prime} 06^{\prime \prime} \mathrm{W}$ \\
\hline Juquiá (SP),Brazil & Btt_Juq1-8 & $24^{\circ} 19^{\prime} 33^{\prime \prime} \mathrm{S} 47^{\circ} 38^{\prime} 22^{\prime \prime} \mathrm{W}$ \\
\hline Araraquara (SP),Brazil & Btt_Ara1 & $23^{\circ} 01^{\prime} 35^{\prime \prime} \mathrm{S} 45^{\circ} 33^{\prime} 21^{\prime \prime} \mathrm{W}$ \\
\hline Rio da Prata,Argentina & Btt_Arg1-2 & NA \\
\hline \multicolumn{3}{|l|}{ B.t.guaibensis } \\
\hline Porto Alegre (RS),Brazil & Btg_POA1-4 & $29^{\circ} 59^{\prime} 52.3^{\prime \prime} \mathrm{S} 51^{\circ} 15^{\prime} 38.6^{\prime \prime} \mathrm{W}$ \\
\hline \multicolumn{3}{|l|}{ B. occidentalis } \\
\hline Ourinhos (SP),Brazil & Boc_Our 1-5 & $22^{\circ} 58^{\prime} 02^{\prime \prime} \mathrm{S} 49^{\circ} 52^{\prime} 25^{\prime \prime} \mathrm{W}$ \\
\hline Martinópolis (SP),Brazil & Boc_Mar1-2 & $22^{\circ} 14^{\prime} 04^{\prime \prime} \mathrm{S} 51^{\circ} 09^{\prime} 36^{\prime \prime} \mathrm{W}$ \\
\hline Presidente Prudente (SP),Brazil & Boc_PPr1 & $22^{\circ} 10^{\prime} 12^{\prime \prime} \mathrm{S} 51^{\circ} 22^{\prime} 34^{\prime \prime} \mathrm{W}$ \\
\hline Candido Mota (SP),Brazil & Boc_CMo1 & $22^{\circ} 44^{\prime} 52^{\prime \prime} \mathrm{S} 50^{\circ} 23^{\prime} 08^{\prime \prime} \mathrm{W}$ \\
\hline
\end{tabular}

NA,Not Available.

Table 1. Collecting data,code and geographical identification of the specimen used in molecular study.

Sequences were corrected using Chromas (Technelysium Pty Ltd.), aligned in ClustalX 1.8 (Thompson et al. 1997). The alignments of COI datasets comprised sequences with no gaps or indels. The alignments were subsequently adjusted by eye using BioEdit 7.0 (Hall, 1999).

Phylogenetic and molecular evolutionary analyses were conducted using MEGA version 5 (Tamura,Peterson,Stecher,Nei,Kumar 2011). Sequence divergence between species was estimated with Kimura 2 parameter model (K2P) (Kimura, 1980). The Neighbor-Joining (Saitou and Nei 1987) trees were obtained using K2P model and the support for the nodes was calculated using 1000 bootstrap replicates (Felsenstein, 1985). Nucleotide diversity (pi,Nei,1987,equations 10.5 or 10.6 and 10.7); and nucleotide divergence between sequence groups ( $D_{x y}$, Nei,1987,equation 10.20 using Jukes and Cantor correction) were calculated using DnaSP v.5 (Librado and Rozas,2009). Fst was estimated following Hudson et al. 1992.

\subsection{Morphology analysis}

The morphological analysis was based on 10 dissected specimens $B$. tenagophila from Arambaré,Rio Grande do Sul (lot DPE 9011); 13 dissected specimens B. t. guaibensis from Porto Alegre,Rio Grande do Sul (lot DPE 9008,Figure 3) and 31 dissected specimens $B$. occidentalis from Tremembé,São Paulo (lot DPE 9028). Only large and adult specimens were used for dissection and anatomic study. 


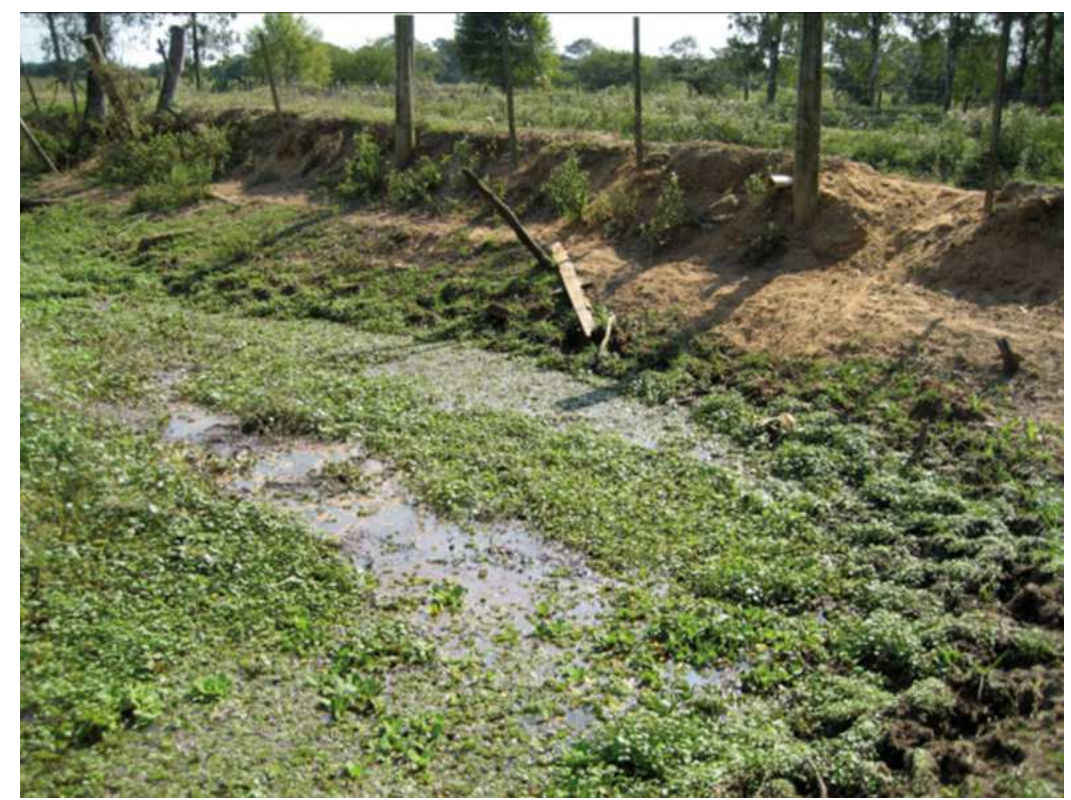

Fig. 3. A natural freshwater habitat at Porto Alegre where B. tenagophila guaibensis were collected. $29^{\circ} 59^{\prime} 523^{\prime \prime} \mathrm{S}, 51^{\circ} 15^{\prime} 38.6^{\prime} \mathrm{W}$.

Snails were identified according to Paraense (1975). Soft parts were preserved under fixation as vouchers. The identification of the mollusks was done under the stereomicroscopy (Leica MZ 95) and was photographed with the image Program IMS 50. We took into consideration the morphology of the shell and soft parts,especially the reproductive system.

Three radulae and three jaws of the B. occidentalis, $B$. tenagophila and B. t. guaibensis were extracted and examined under a Scanning Electron Microscope LEO 440 at the Museum of the Zoology,São Paulo University (MZUSP).

\section{Results}

\subsection{Molecular analysis}

The evolutionary relationships of tenagophila complex were inferred using Neighbor-Joining method for COI and 16SrRNA mitochondrial genes (Figure 4). The evolutionary distances depicted as branch lengths were computed using the Kimura $2 p$ method using 550 nucleotides positions for the COI dataset and 314 nucleotide positions for the 16S rRNA dataset. The tenagophila complex sequences were retrieved in two well distinct and bootstrap supported branches: one with B. occidentalis clustering with B. t. guaibensis, and another distinct branch with the nominal B.tenagophila sequences.

For each component that belongs to tenagophila complex we obtained intraspecific identical sequences that support morphological taxonomy.

Two distinct groups of $B$. tenagophila were recovered in each analysis (COI and rRNA16S). The estimates of genetic divergence (Table2) under Kimura $2 p$ model over the COI and $16 \mathrm{~S}$ between sequences pairs of the taxa analyzed show that $B$. t. guaibensis are more closely related with $B$. occidentallis than with $B$. tenagophila. 


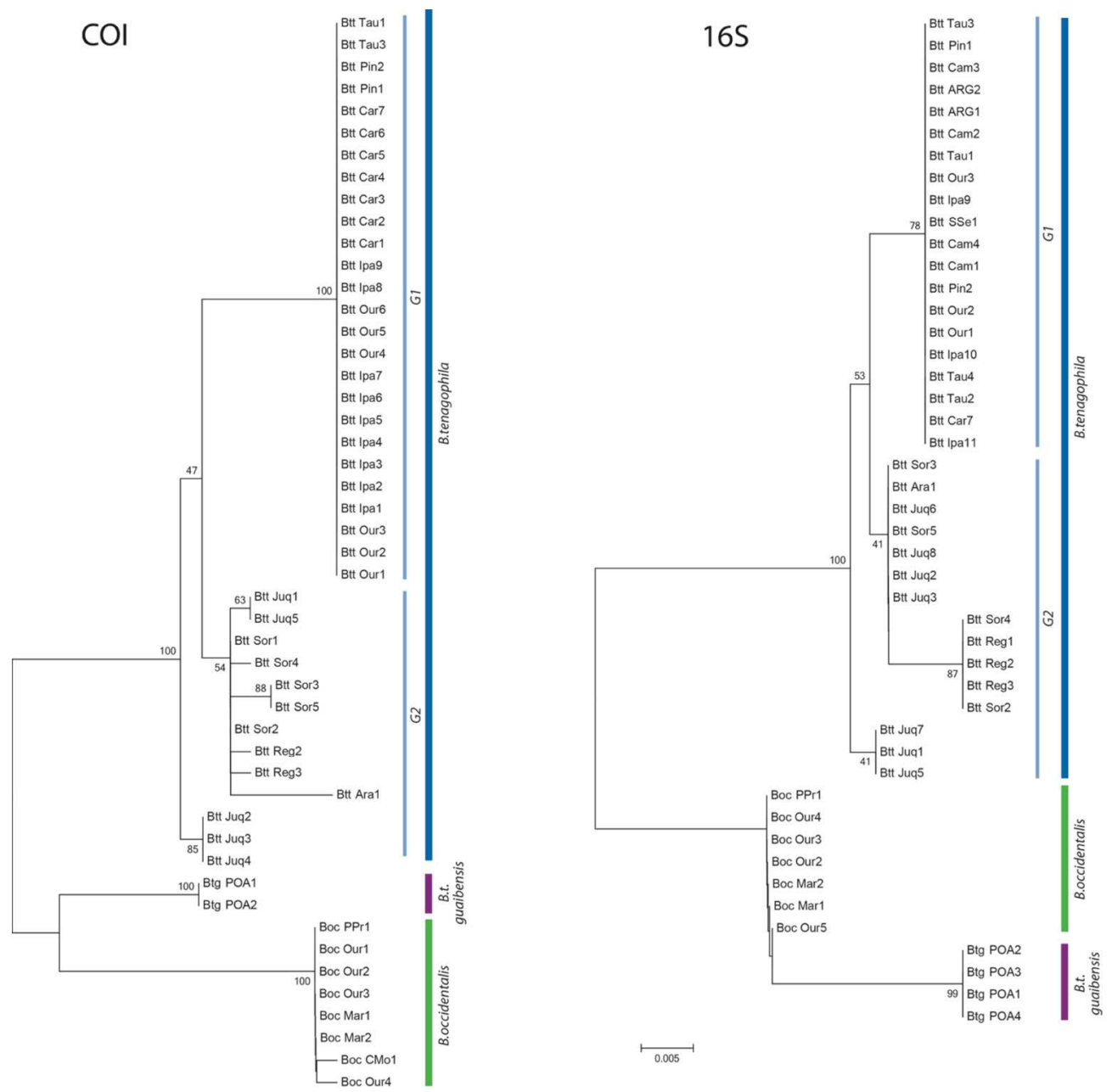

Fig. 4. Optimal trees inferred for a 550 fragment COI mtDNA(A),sum of branch length= 0.09775397 , and for a 314 nucleotides 16SrRNA,sum of branch length $=0.07712277$. Bootstrap values (1000 replicates) are shown next to the branches.

\begin{tabular}{|l|l|l|l|}
\hline Species 1 & Species 2 & COI & 16 S \\
\hline B.tenagophila & B.t.guaibensis & 0.0436 & 0.0668 \\
\hline B.tenagophila & B.occidentalis & 0.0546 & 0.0478 \\
\hline B.t.guaibensis & B.occidentalis & 0.0362 & 0.0178 \\
\hline
\end{tabular}

Table 2. Mean Pairwise distance values calculated under Kimura's 2 -parameter model (K2P) for 49 COI sequences and 46 16SrRNA sequences. 
The Figure 5 shows that no overlap exists between intraspecific and interspecific distribution distance calculated under Kimura 2P. Indeed, the distributions of the COI and $16 \mathrm{~S}$ genetic distances are very similar (Figure 5).
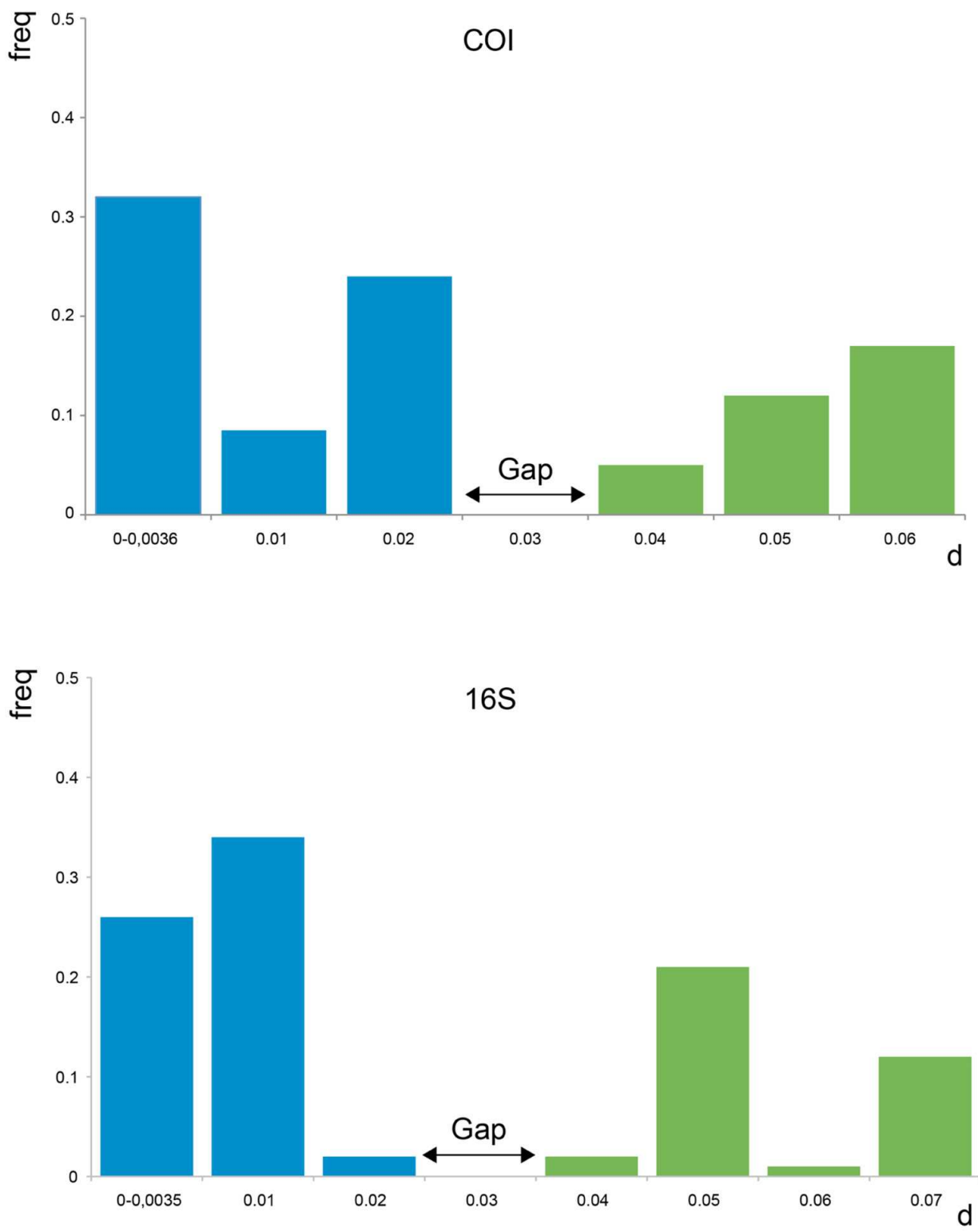

Fig. 5. Distribution of intraspecific variation genetic distance (in blue bars), and interspecific distance (in green bars) estimated by Kimura's 2 -parameter model (K2P) for all the species studied 
In order to examine the ability of the barcoding methodology to identify the three Biomphalaria taxa we plotted the intra and interspecific divergence of COI and 16S using a threshold of $3 \%$ minimum interspecific genetic variation and 3\% maximum intraspecific genetic variation (Figure 6).

According the 3\% threshold value for within and between species variation four quadrants are defined. Species on quadrant I (dark grey) are well-defined species. Groups on quadrant II (white colored) are composite species. Species on quadrant III (medium grey) are recent divergent species, and species on quadrant IV (light grey) are misidentified species.

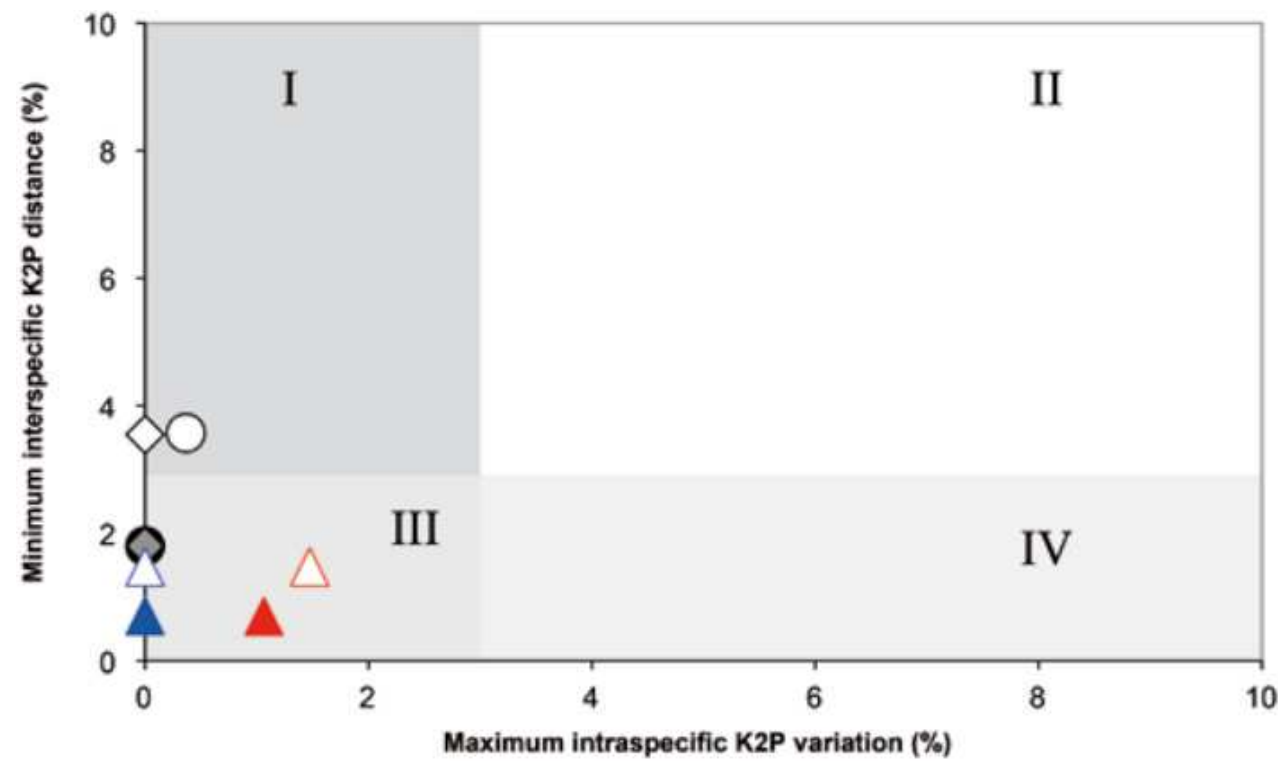

\begin{tabular}{|c|c|c|c|c|}
\hline $16 S$ & B. occidentalis & B.t. guaibensis & A B. tenagophila 1 & A B. tenagophila 2 \\
\hline $\mathrm{COI}$ & B. occidentalis & $\checkmark$ B.t. guaibensis & $\triangle$ B. tenagophila 1 & $\triangle$ B. tenagophila 2 \\
\hline
\end{tabular}

Fig. 6. Minimum Interspecific distances versus Maximum intraspecific distances of COI and $16 \mathrm{~S}$ sequences for B. tenagophila,B. occidentalis and B. t. guaibensis (according Ballard et al.,2009).

\subsection{Comparative analysis of shell,reproductive system and radula}

B. tenagophila,B.t. guaibensis and B. occidentalis had no significant differences among the number of whorls. The species had typically six to eight whorls. Otherwise,the shell aperture would be shorter and narrower in B.t guaibensis than in the other two species analyzed (Figure 7). 

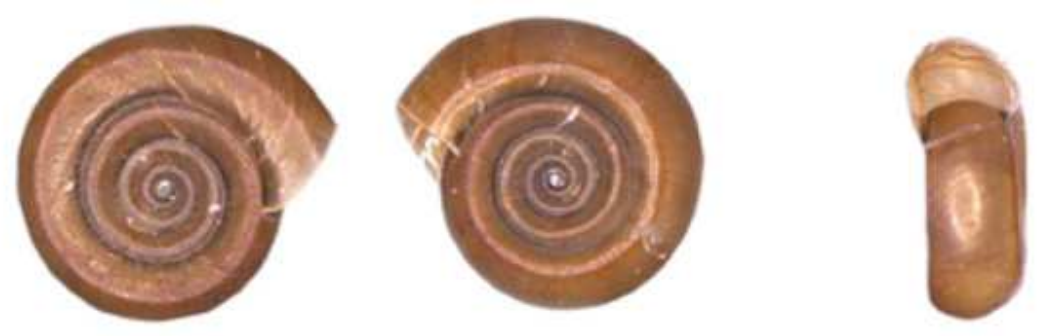

A
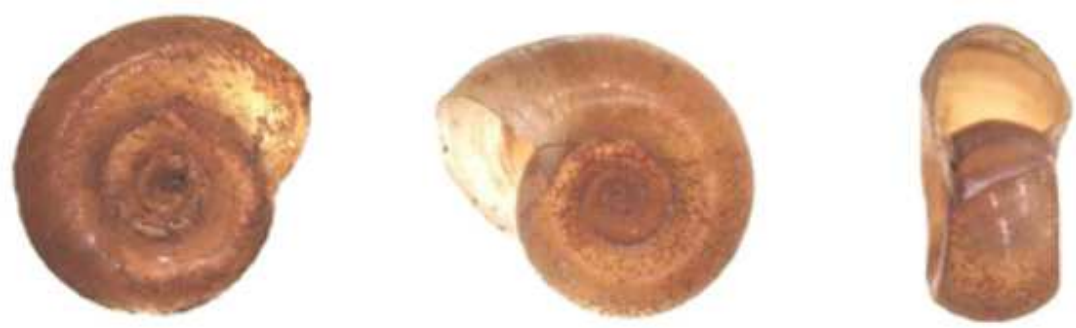

B
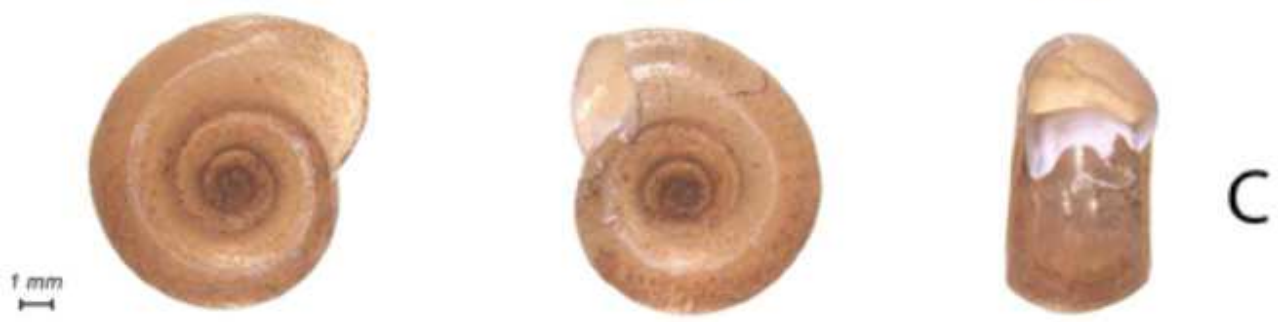

Fig. 7. Shell. A: B. t. guaibensis Biomphalaria tenagophila, C: B. occidentalis

Biomphalaria snails can be distinguished based on differences in the shape and size of their male and female internal organs as described in Figure 8. 


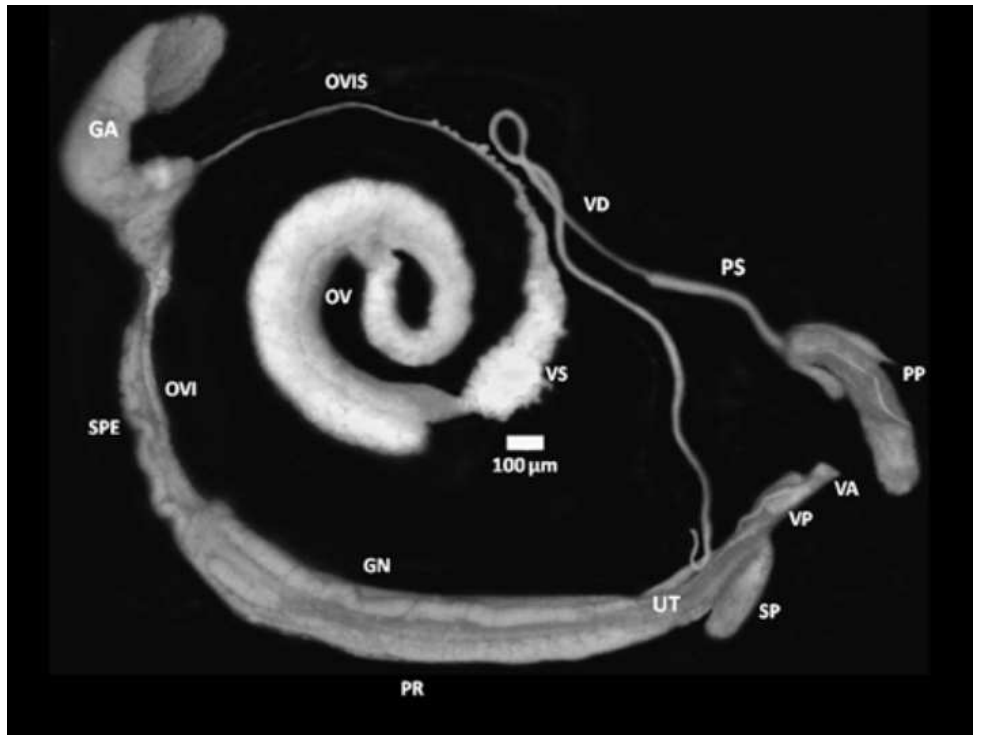

Fig. 8. Reproductive System from Biomphalaria tenagophila. GA: albumen gland,GN: nidamental gland,OV: ovotestis,OVI: oviduct,OVIS: ovispermiduct,PP: prepuce,PR: prostate,PS: penial sheath,SP: spermatheca,SPE: spermiduct,UT: uterus,VA: vagina,VD: vas deferens,VP: vaginal pouch, VS: seminal vesicle.

The hermaphrodite part did not present differences between B.tenagophila,B.t. guaibensis and B. occidentalis.

The differences between the species were mainly found in the male and female systems. The anatomical characters that clearly groups B.tenagophila and B. t. guaibensis in a same taxon is a well developed vaginal pouch located in the vaginal wall of this species,and also the shape and size of the prepuce and the volume of prostata (Table 5,Figure 9).

\begin{tabular}{|c|c|c|c|}
\hline & Biomphalaria tenagophila & $\begin{array}{c}\text { Biomphalaria tenagophila } \\
\text { guaibensis }\end{array}$ & Biomphalaria occidentalis \\
\hline Vagina & short & Long and slender & Long and slender \\
\hline $\begin{array}{l}\text { Vaginal } \\
\text { pouch }\end{array}$ & Well developed & Well developed & absent \\
\hline penis & thick & Long and slender & Long and slender \\
\hline prepuce & $\begin{array}{l}\text { Wider at the free end of } \\
\text { the prepuce }\end{array}$ & $\begin{array}{l}\text { Wider at the free end of } \\
\text { the prepuce }\end{array}$ & $\begin{array}{c}\text { Same diameter along the } \\
\text { prepuce }\end{array}$ \\
\hline Penis sheath & $\begin{array}{l}\text { Shorter and slenderer } \\
\text { than the prepuce }\end{array}$ & $\begin{array}{l}\text { Shorter and slenderer } \\
\text { than the prepuce }\end{array}$ & $\begin{array}{l}\text { Shorter and slenderer } \\
\text { than the prepuce }\end{array}$ \\
\hline Próstata & $\begin{array}{l}\text { Robust with a great } \\
\text { number of diverticula }\end{array}$ & $\begin{array}{l}\text { Robust with a great } \\
\text { number of diverticula }\end{array}$ & $\begin{array}{l}\text { Refined with a small } \\
\text { number of diverticula }\end{array}$ \\
\hline spermatheca & large & small & small \\
\hline
\end{tabular}

Table 5. Differences among B. tenagophila species complex based on reproductive parameters 

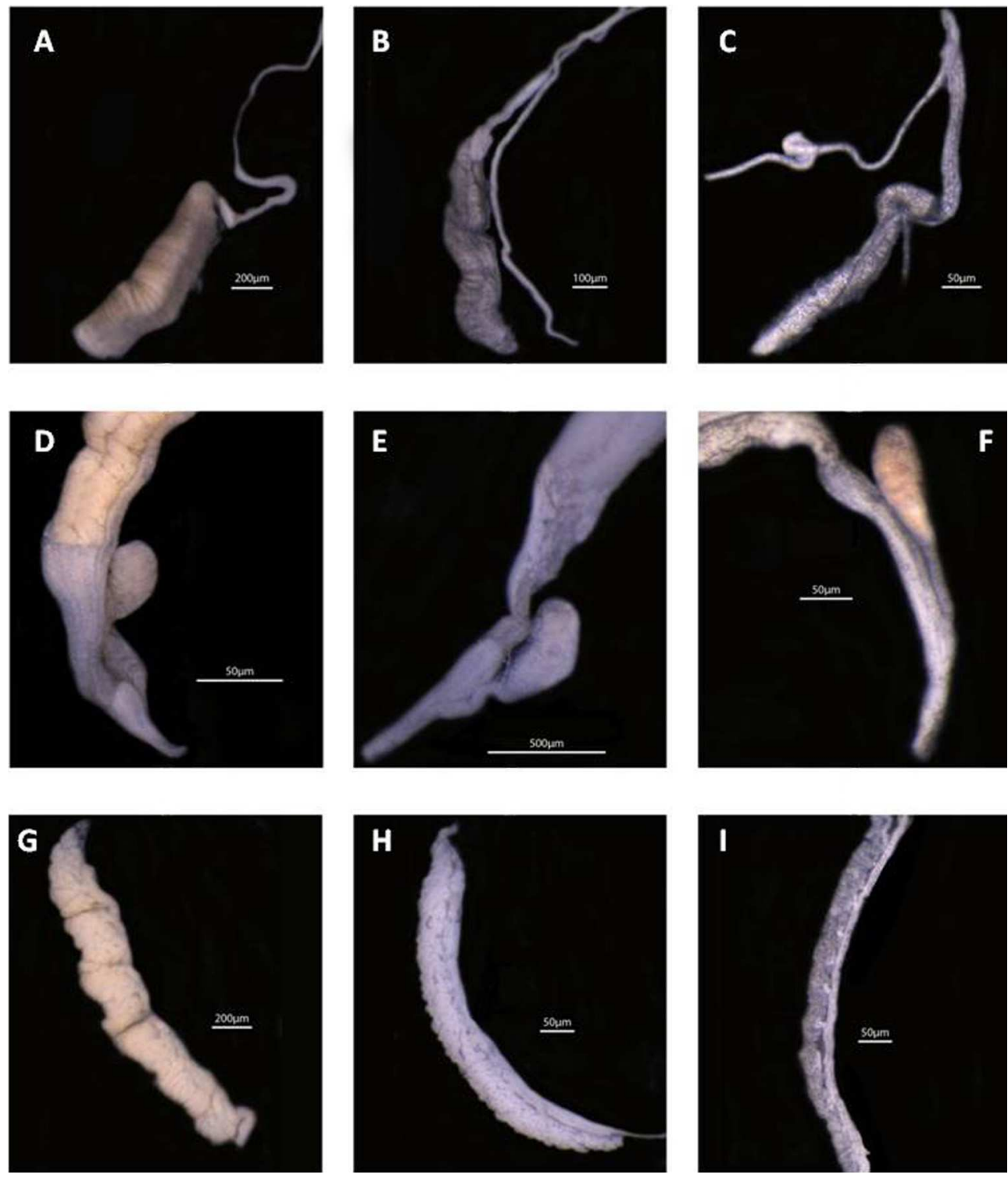

Fig. 9. Detail of reproductive system. A,D and G: B. tenagophila, B,E and H: B. t. guaibensis,C,F and I: B. occidentalis. A,B and C: Penis; D,E and F: Vaginal complex; G,H and I: Prostate

The radulae of $B$ tenagophila,B. t. guaibensis and B. occidentalis consisted of a fused jaw (Figure $10)$ to which the teeth are attached. 


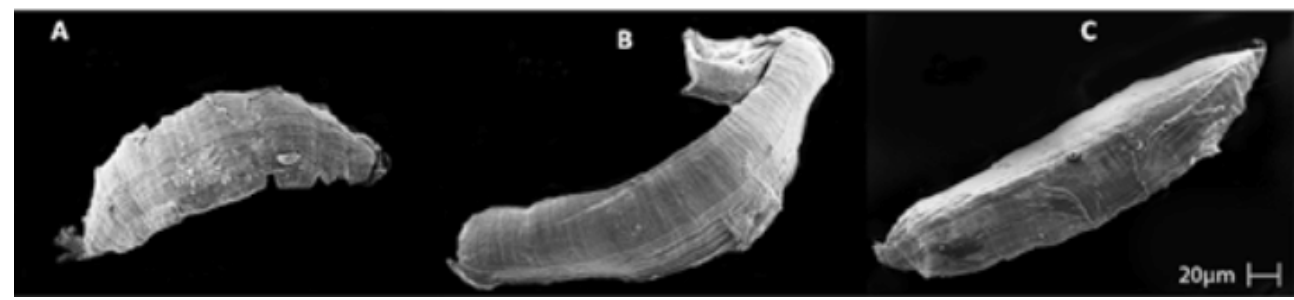

Fig. 10. Mandíbula. A.: B. tenagophila,B.: B.t. guaibensis, C: B. occidentalis.

In all the species analyzed there was only one central tooth with two cusps and several lateral teeth at each side of the central tooth. In B.t. guaibensis the central tooth showed variations that affected the inner and outer faces of the cuspids (Figure 11).
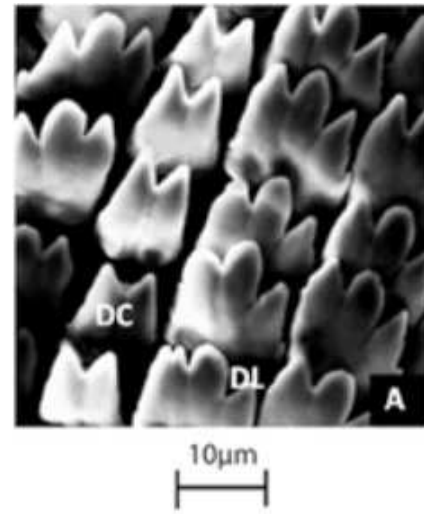

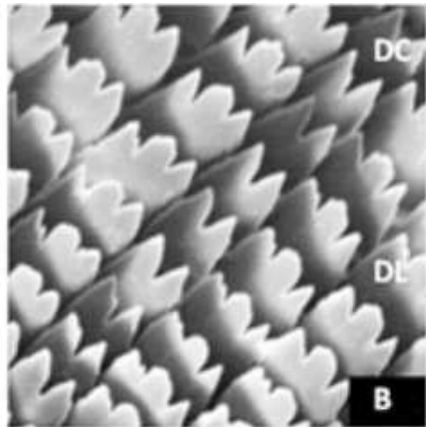

$10 \mu \mathrm{m}$
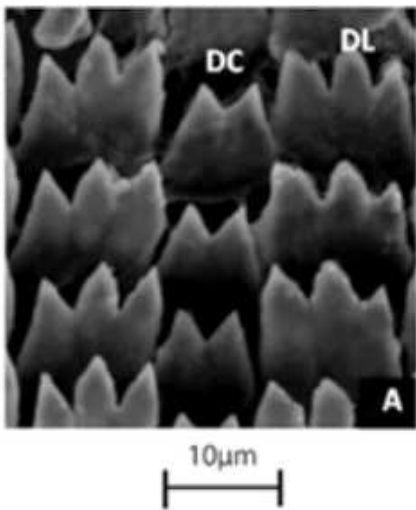

Fig. 11. Radula. A: B. tenagophila,B: B.t. guaibensis,C: B. occidentalis. DC: central tooth,DL: lateral teeth.

In all the three species the lateral were characterized with three cuspids. Small subcusps appear on lateral teeth near the margins given a serrated appearance for the radulae. (Figure 12)
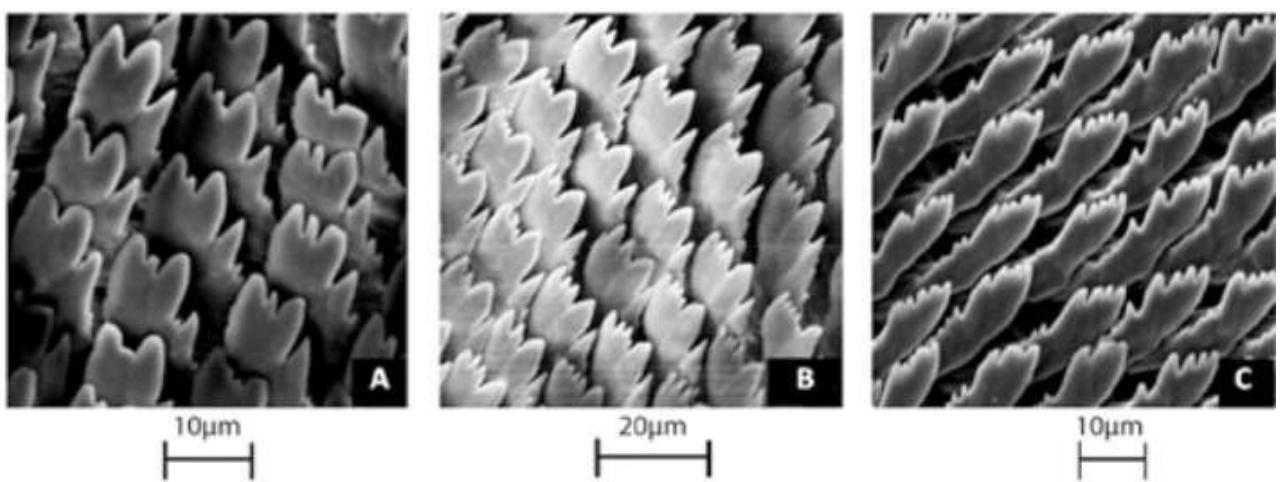

Fig. 12. Marginal teeth of the radula. A: B. tenagophila,B: B.t. guaibensis,C: B. occidentalis. 


\section{Discussion}

Phylogenetic analysis using short sequences of the mitochondrial COI and 16SrRNA genes resulted in trees with high support values morphologycally pairs of species $B$. tenagophila and the subspecies B.t. guaibensis, and the B. occidentalis and B. $t$ guaibensis, assigned as tenagophila species complex (Figure 4).

The molecular evidence thus strongly suggests that B. occidentalis and B.t. guaibensis are part of a clade of closely related species with a minimal genetical divergence between them (Table 2).

The result obtained here is in perfect agreement with our observations with respect to the resemblance between guaibensis and occidentalis morphology,both thin and elongated species when compared to tenagophila species. For taxonomically purposes, the vaginal pouch places $B$. tenagophila and B.t. guaibensis closer to each other (Paraense,1984). The vaginal pouch represents a character easy to score unambiguously ( 1 for presence 0 for absence) but instead of inferring a close relationship between B.tenagophila and B.t guaibensis, the vaginal pouch could also be considered a case of homoplasy and might not have great confidence and definition for such a complex taxonomic groups as in other gastropod groups (Collin,2003). To sustain such hypothesis,further additional sequences from other sites are clearly required.

Our sequence data (COI,16S) revealed significant intraspecific variation for B. tenagophila. Two major branches were resolved by phylogenetic analysis,one of which -G1- with very low internal variation (pi=0.0000 for COI and 16S) and a second branch -G2- with a significant degree of internal genetic differentiation amongst sequences ( $\mathrm{pi}=0.00587$ for COI and $\mathrm{pi}=0.00995$ for $16 \mathrm{~S}$ ).

The extremely low levels of genetic variation in G1 branch exists amongst populations across a broad geographic range area,including Ourinhos,Pindamonhangaba and Taubate. All these sites presented were in the past active areas of transmission of schistosomiasis (Piza,1972; Silva,1985),subjected to intensive use of moluscicide measure that resulted in cycles of extinction followed by recolonization of B. tenagophila (Tuan,1996).

Whereas G1 population occurs in historical unstable sites,G2 population inhabits freshwater sites at São Paulo (Registro,Juquia) with fragments of the Brazilian Atlantic Rain Forest,one of the most important hot- spots of genetic diversity in the world (Carnaval et al. 2009). The significant differentiation between G1 and G2 B. tenagophila populations (Fst COI= 0.82; Fst 16S=0.77) and the retention of even a small genetic diversity in G2 populations could be due to historical signatures since Atlantic coastal regions played an important role as a climatic refugee during the last Pleistocene (Pfenninger and Posada,2009). A taxonomist working with a series of snails of this species collected over a broad geographical range certainly would not recognize any significant morphological variation. This shows the lack of resolution of morphology and that DNA barcoding data can direct us to what we need to look further into: biodiversity.

According to Moritz and Cicero (2004) "accurate diagnosis" by a short COI DNA sequence," depends on low intraspecific variation compared with that between species" So we can conclude that COI and $16 \mathrm{~S}$ may be used for detection of species in B. tenagophila complex species (Figure 5). Furthermore,mtDNA lineages found in B. tenagophila may help explain heterogeneous patterns of schistosomiasis transmission.

\section{Acknowledgments}

We thank Lucia MZ Richinitti from PUCRS for collecting specimens in RS,Brazil,and Dr. Eliana Zanotti-Magalhães from UNICAMP for donating snails from Rio da Prata used in 
this study. This work was supported by FAPESP (Fundação de Amparo a Pesquisa do Estado de São Paulo) Grant 2007/03458-7 for Roseli Tuan and 2008/57792-8 for Fernanda Pires Ohlweiler.

\section{References}

Ballard, J. W. O.; Puslednik, L.; Wolff, J. N.; Russell, R. C. (2009). Variation Under Nature: A Sesquicentennial DNA Barcoding Perspective. Chiang Mai J. Sci. Vol. 36, No. 2, pp.188-199, ISSN 0125-2526

Brasil. Ministério da Saúde. (2007). Vigiláncia e Controlde de Moluscos de ilmportáncia Epidemiológica: diretrizes técnicas: Programa de Vigilância e Controle da Esquistossomose (PCE). Ministério da Saúde (Ed.), Brasilia, 178p. ISBN 978-85-3341438-9

Carnaval, A. C.; Moritz, C.; Hickerson, M.; Haddad, C.; Rodrigues, M. (2009). Stability predicts diversity in the Brazilian Atlantic Forest hotspot. Science, Vol. 323, No. 5915, pp.785-789, ISSN 0036-8075

Carvalho, O. S.; Amaral R. S.; Dutra, L. V.; Scholz, R. G. C.; Guerra, M. A. M. (2008). Distribuição Espacial de Biomphalaria glabrata, B. straminea e B. tenagophila, Hospedeiros Intermediários do Schistosoma mansoni no Brasil. In: Schistosoma mansoni e esquistossomose: uma visão multidisciplinar, Fiocruz, (Ed.), , Rio de Janeiro, Brasil, pp.393-418, ISBN: 978-857541-150-6

Carvalho, O. S.; Caldeira R. L.; Simpson, A. J.; Vidigal, T. H. (2001). Genetic variability and molecular identification of Brazilian Biomphalaria species (Mollusca: Planorbidae). Parasitology, Vol. 123, pp.197-209, ISSN 0031-1820

Carvalho, O. S.; Caldeira, R. L. Identificação morfologica de Biomphalaria glabrata, B. tenagophila e B. straminea hospedeirosintermediários do Schistoma mansoni. Belo Horizonte: Centro depesquisas René Rachou/Fiocruz, 2004. 1 CD. (Série Esquistossomose; n.6).

Collin, R. (2003). The utility of morphological characters in gastropod phylogenetics: an example from the Calyptraeidae. Biological Journal of the Linnean Society, Vol 78, No. 4, pp.541-593, ISSN 1095-8312

DeJong, R. J.; Morgan, J. A.; Paraense, W. L.; Pointier, J. P.; Amarista, M.; Ayeh-Kumi, P. F.; Babiker, A.; Barbosa, C. S.; Bremond, P.; Pedro Canese A.; Souza, C. P. de.; Dominguez, C.; File, S.; Gutierrez, A.; Incani, R. N.; Kawano, T.; Kazibwe, F.; Kpikpi, J.; Lwambo, N. J.; Mimpfoundi, R.; Njiokou, F.; Noel Poda, J.; Sene, M.; Velasquez, L. E.; Yong, M.; Adema, C. M.; Hofkin, B. V.; Mkoji, G. M.; Loker, E. S. (2001). Evolutionary relationships and biogeography of Biomphalaria (Gastropoda: Planorbidae) with implications regarding its role as host of the human bloodfluke, Schistosoma mansoni. Mol Biol Evol. Vol. 18, No. 12, pp. 2225-2239, ISSN 0737-4038

DeJong, R. J.; Morgan, J. A.; Wilson, W. D.; Al-Jaser, M. H.; Appleton, C. C.; Coulibaly, G.; D'Andrea, P. S.; Doenhoff, M. J.; Haas W.; Idris, M. A.; Magalhaes, L. A.; Mone, H.; Mouahid, G.; Mubila, L.; Pointier, J. P.; Webster, J. P.; Zanotti-Magalhaes, E. M.; Paraense, W. L.; Mkoji, G. M.; Loker, E. S. (2003). Phylogeography of Biomphalaria glabrata and B. pfeifferi, important intermediate hosts of Schistosoma mansoni in the New and Old World tropics. Mol Ecol. Vol. 12, No. 11, pp. 3041-3056, ISSN 1365$294 X$ 
Deslandes, N. 1959. Técnica de dissecção e exame de planorbídeos. Rev. Serv. Espec. Saúde Publica Vol.4, pp. 371-382

Estrada, E. V. E.; Velásquez, L. E.; Caldeira, R. L.; Bejarano, E. E.; Rojas, W.; Carvalho, O. M. (2006). Phylogenetics of South American Biomphalaria and description of a new species (Gastropoda: Planorbidae). J. Mollus. Stud, Vol. 72, No.3, pp. 221-228, ISSN 0260-1230

Felsenstein J. (1985). Confidence limits on phylogenies: An approach using the bootstrap. Evolution, Vol. 39, No. 4, pp. 783-791

Folmer, O.; Black, M.; Hoeh, W.; Lutz, R.; Vrijenhoek, R. (1994). DNA primers for amplification of mitochondrial cytochrome $\mathrm{c}$ oxidase subunit I from diverse metazoan invertebrates. Molecular Marine Biology and Biotechnology.Vol. 3, No.5, pp. 294-299, ISSN 1053-6426

Guimarães, M. C. A. (2003). Estudo comparativo dos aspectos reprodutivos de duas populações de B. tenagophila (Orbigny 1835) de áreas com e sem transmissão de esquistossomose no estado de São Paulo. Dissertação de Mestrado em Epidemiologia da Faculdade de Saúde Pública, Universidade de São Paulo, USP, Brasil.

Hall, T. A. (1999). BioEdit: a user-friendly biological sequence alignment editor and analysis program for Windows 95/98/NT. Nucl Acids Symp Ser. Vol. 41, pp. 95-98

Hudson, R. R.; Slatkin, M; Maddison, W. P. (1992). Estimation of levels of gene flow from DNA sequence data. Genetics, Vol.132, pp. 583-589, ISSN 0016-673

Kimura, M. (1980). A simple method for estimating evolutionary rate of base substitutions through comparative studies of nucleotide sequences. Journal of Molecular Evolution, Vol. 16, pp. 111-120, ISSN 0022-2844

Librado, P.; Rozas, J. (2009). DnaSP v5: software for comprehensive analysis of DNA polymorphism data. Bioinformatics, Vol.25, No. 11, pp. 1451-1452, ISSN 1367-4803

Lima, L. C.; Soares, D. M.; Guimarães, C. T. (1993).Biomphalaria occidentalis paraense, 1981 in the state of Minas Gerais, Brazil. Mem. Inst. Oswaldo Cruz, vol.88, No.2, pp.289292, ISSN 0074-0276

Majoros, G.; Fehér, Z.; Deli T; Földvári, G. (2008). Establishment of Biomphalaria tenagophila Snails in Europe. Emerging Infectious Disease Vol.14, No. 11 (Nov 2008), pp.18121814, ISSN 1080-6059

Mavárez, J.; Pointier, J-P.; David, P.; Delay, B.; Jarne, P. (2002). Genetic differentiation, dispersal and mating system in the schistosome-transmiting freshwater snail Biomphalaria glabrata. Heredity, Vol.89, No. 4, pp.258-265, INSS 0018-067X

Mavárez, J.; Steiner C.; Pointier, J-P.; Jarne, P. (2002). Evolutionary history and phylogeography of the schistosome-vector freshwater snail Biomphalaria glabrata based on nuclear and mitochondrial DNA sequences. Heredity, Vol.89, No. 4, pp. 266-272, INSS 0018-067X.

Morgan, J.A., DeJong, R. J., Jung Y., Khallaayoune, K.; Kock S; Mkoji, G. M.; Loker, E. S. (2002).A phylogeny of planorbid snails, with implications for the evolution of Schistosoma parasites. Moecular Phylogenetics Evolution.Vol. 25, No. 3, pp. 477-488. ISSN 1055-7903

Moritz, C. \& Cicero, C. (2004). DNA Barcoding: Promise and Pitfalls. PLos Biology, Vol. 2, No. 10, pp. 1529-1531 
Nei, M. (1987). Molecular Evolutionary Genetics. Columbia University Press, New York, USA, 448p.

Ohlweiler, F. P.; Kawano, T. (2002) Biomphalaria tenagophila (Orbigny, 1835) (Mollusca): adaptation to desiccation and susceptibility to infection with Schistosoma mansoni Sambon, 1907. Rev. Inst. Med. Trop. S. Paulo, Vol. 44, No. 4, pp. 191-201. ISSN 0036-4665

Palasio, R.G.S. (2011). Estudo da variabilidade genética e morfológica de Biomphalaria tenagophila Orbigny 1835 (Gastropda, Planorbidae) procedente do Vale do Rio Ribeira do Iguape e do Litoral Norte do Estado de Sao Paulo. Projeto de Mestrado, UNICAMP, São Paulo, 32p

Palumbi, S. R. (1996). Nucleic acids II: the polymerase chain reaction. In: Molecular Systematics, Hillis DM, Moritz C, Mable BK (Eds.), pp. 205 - 247, Sinauer \& Associates Inc., ISBN 0-87893-282-8, Sunderland, Massachusetts.

Paraense, W. L. (1955). Autofecundação e fecundação cruzada em Australorbis glabratus. Mem. Inst. Oswaldo Cruz. Vol.53, Nos. 2-3-4, (Jun/Dec 1955) pp. 277-291. ISSN 0074-0276.

Paraense, W. L. (1975). Estado atual da sistemática dos planorbídeos brasileiros. Arq. Mus. Nac. Rio de Janeiro. Vol. 55 (1975), pp. 105-128.

Paraense, W. L. (1981). Biomphalaria occidentalis SP.N. from South America (Mollusca: Basommatophora: Pulmonata). Mem Inst Oswaldo Cruz, Vol. 76, No. 2, (Apr/Jun 1981)2, pp. 199- 211, ISSN 0074-0276

Paraense, W. L. (1984). Biomphalaria tenagophila guaibensis ssp. n. from southern Brazil and Uruguay (Pulmonata: Planorbidae). I. Morphology. Mem Inst Oswaldo Cruz, Vol. 79, No. 4 (oct./dec 1984), pp. 465-469, ISSN 0074-0276.

Paraense, W.L. (2001) The schistosome vectors in the Americas. Mem. Inst.Oswaldo Cruz. vol. 96, pp. 7-16

Paraense, W. L., Deslandes N. (1959). The renal ridge as a reliable character for separating Taphius glabratus from Taphius tenagophilus. Am J Trop Med Hyg, Vol. 8, (Jul 1959) pp. 456-472, INSS 0002-9637.

Paraense, W. L. \& Correa L.R. (1978). Differencial susceptibility of Biomphalaria tenagophila populations to infection with a strain of Schistosoma mansoni. J Parasitol, Vol. 64, No. 5, pp. 822-826

Pepe, M. S.; Caldeira R. L.; Carvalho O. S.; Muller G.; Jannotti-Passos, L. K.; Rodrigues A. P.; Amaral H. L.; Berne M. E. A. (2009). Biomphalaria molluscs (Gastropoda: Planorbidae) in Rio Grande do Sul, Brazil. Mem Inst Oswaldo Cruz, Rio de Janeiro, Vol. 104, No. 5, pp. 783-786, INSS 0074-0276

Pfenninger M. \& Posada D.(2002). Phylogeographic history of the land snail candidula unifasciata (Helicellinae, Stylommatophora): Fragmentation, corridor migration, and secondary contact. Evolution, Vol.56, No. 9, pp. 1776-1788

Piza, J.T., Ramos, A.S., Moraes, L.V.C., Correa, R.R., Takaku, L. \& Pinto, A.C.M. (1972). Carta Planorbídica do Estado de São Paulo. Secretaria da Saúde do Estado de São Paulo, São Paulo. Campanha de Combate à Esquistossomose.

Pointier, J-P.; DeJong, R. J.; Tchuem Tchuenté, L. A.; Kristensen, T. K.; Loker, E. S. (2005). A neotropical snail host of Schistosoma mansoni introduced into Africa and consequences for the schistosomiasis transmission: Biomphalaria tenagophila in 
Kinshasa (Democratic Republic of Congo). Acta Tropica Vol. 93, No. 2, pp.191-199, ISSN 0001-706X

Saitou N. \& Nei M. (1987). The neighbor-joining method: a new method for reconstructing phylogenetic trees. Mol Biol Evol, Vol. 4, No. 4, pp. 406-425, ISSN 0737-4038

Silva L. J. (1985). Urban growth and disease: schistosomiasis in the municipality of S. Paulo (Brazil). Rev. Saúde Pública, Vol. 19, No. 1, pp. 1-7, ISSN 0034-8910

Spatz L.; Vidigal, T. H. D. A.; Caldeira, R.L.; Dias Neto, E.; Cappa, S. M. G.; Carvalho, O. S. (1999). Study of Biomphalaria tenagophila tenagophila, B. t. guaibensis and B. occidentalis by polymerase chain reaction amplification and restriction enzyme digestion of the ribosomal RNA intergenic spacer regions. Journal Molluscan Studies., Vol. 65, No. 2, pp. 143-149, ISSN 0260-1230

Tamura K.; Peterson, D.; Peterson, N.; Stecher, G.; Nei, M.; Kumar, S. (2011). Mega5: Molecular Evolutionary Genetics Analysis using Maximum Likelihood, Evolutionary Distance, and Maximum Parsimony Methods. Molecular Biology and Evolution. (to be submitted).

Teodoro, T. M.; Janotti-Passos, L. K.; Carvalho, O. S.; Caldeira, R. L. (2010). Occurrence of Biomphalaria cousini (Mollusca: Gastropoda) in Brazil and its susceptibility to Schistosoma mansoni (Platyhelminths: Trematoda), Molecular Phylogenetics and Evolution, Vol. 57, No. 1, pp. 144-151, ISSN 1055-7903

Thompson, J. D.; Gibson, T. J.; Plewniak, F.; Jeanmougin, F.; Higgins, D. G. (1997). The Clustal X windows interface: flexible strategies for multiple sequence alignment aided by quality analysis tools. Nucleic Acids Res. Vol. 25, No. 24, pp. 4876-4882. ISSN 0305-1048

Tuan, R. \& Santos, P. dos. (2007). ITS2 variability of Biomphalaria (Mollusca, Planorbidae) species from the Paranapanema Valley (São Paulo State, Brazil): Diversity patterns, population structure, and phylogenetic relationships. Genetics and Molecular Biology, Vol. 30, No. 1, pp. 139-144, ISSN 1415-4757

Tuan, R. \& Simões, L. C. G. (1989). Effect of self-fertilization on Biomphalaria tenagophila (Orbigny, 1835) (Pulmonata: Planorbidae). Genet. Mol. Biol. Vol. 21, No. 4, pp. 477478, ISSN 1415-4757

Tuan, R. (1996). Biologia de Biomphalaria tenagophila (Pulmonata:Planorbidae) em relação ao uso do moluscicida químico Bayluscide (Bayer): implicações para o controle. Tese de Doutorado em Ciências Biológicas (Biologia Genética), Universidade de São Paulo, USP, Brasil.

Tuan, R. \& Simões L. C. G. (1989). Spermatogenesis and desiccation in Biomphalaria tenagophila (Orbigny, 1985) (Gastropoda, Planorbidae). Braz J Genetic, Vol.12, No. 4, pp. 881-5

Vidigal, T. H.; Spatz, L.; Kissinger, J. C.; Redondo, R. A.; Pires, E. C.; Simpson, A. J.; Carvalho, O. S. (2004). Analysis of the first and second internal transcribed spacer sequences of the ribosomal DNA in Biomphalaria tenagophila complex (Mollusca: Planorbidae). Mem Inst Oswaldo Cruz, Rio de Janeiro, Vol. 99, No. 2, pp. 153-158, ISSN 0074-0276

Vidigal, T. H. D. A.; Kissinger, J. C.; Caldeira, R. L.; Pires, E. C. R.; Monteiro, E.; Simpson, A. J. G.; Carvalho, O. S. (2000). Phylogenetic relationships among Brazilian Biomphalaria species (Mollusca: Planorbidae) based upon analysis of ribosomal ITS2 sequences. Parasitology, Vol. 121, No. 6, pp. 611-620, ISSN 0031-1820 


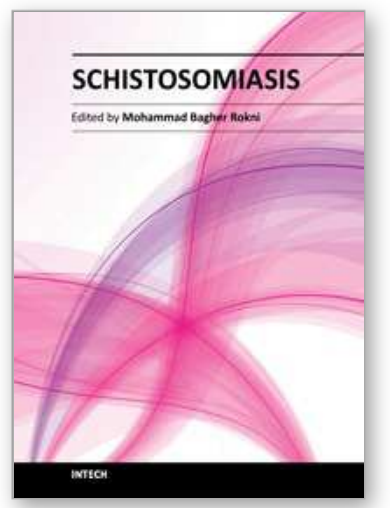

\author{
Schistosomiasis \\ Edited by Prof. Mohammad Bagher Rokni
}

ISBN 978-953-307-852-6

Hard cover, 310 pages

Publisher InTech

Published online 13, January, 2012

Published in print edition January, 2012

In the wake of the invitation by InTech, this book was written by a number of prominent researchers in the field. It is set to present a compendium of all necessary and up-to-date data to all who are interested.

Schistosomiasis or blood fluke disease, also known as Bilharziasis, is a parasitic disease caused by helminths from a genus of trematodes entitled Schistosoma. It is a snail-borne trematode infection. The disease is among the Neglected Tropical Diseases, catalogued by the Global Plan to combat Neglected Tropical Diseases, 2008-2015 and is considered by the World Health Organization (WHO) to be the second most socioeconomically devastating parasitic disease, next to malaria. WHO demonstrates that schistosomiasis affects at least 200 million people worldwide, more than 700 million people live in endemic areas, and more than 200.000 deaths are reported annually. It leads to the loss of about 4.5 million disability-adjusted life years (DALYs).

\title{
How to reference
}

In order to correctly reference this scholarly work, feel free to copy and paste the following:

Roseli Tuan, Fernanda Pires Ohlweiler, Raquel Gardini Sanches Palasio, Ricardo Dalla Zanna and Marisa Cristina De Almeida Guimarães (2012). Pattern of Genetic Divergence of Mitochondrial DNA Sequences in Biomphalaria tenagophila Complex Species Based on Barcode and Morphological Analysis, Schistosomiasis, Prof. Mohammad Bagher Rokni (Ed.), ISBN: 978-953-307-852-6, InTech, Available from: http://www.intechopen.com/books/schistosomiasis/pattern-of-genetic-divergence-of-mitochondrial-dnasequences-in-biomphalaria-tenagophila-complex-spe

\section{INTECH}

open science | open minds

\section{InTech Europe}

University Campus STeP Ri

Slavka Krautzeka 83/A

51000 Rijeka, Croatia

Phone: +385 (51) 770447

Fax: +385 (51) 686166

www.intechopen.com

\section{InTech China}

Unit 405, Office Block, Hotel Equatorial Shanghai

No.65, Yan An Road (West), Shanghai, 200040, China 中国上海市延安西路65号上海国际贵都大饭店办公楼 405 单元

Phone: +86-21-62489820

Fax: +86-21-62489821 
(C) 2012 The Author(s). Licensee IntechOpen. This is an open access article distributed under the terms of the Creative Commons Attribution 3.0 License, which permits unrestricted use, distribution, and reproduction in any medium, provided the original work is properly cited. 